are in favour of building it if it does not imperil the budgetary restrictions outlined here, which makes it something of a problem. On the other hand, the committee does emphasize the urgent need for drastic reorganization, bringing together again all the activity at present dispersed and, above all, recovering the work now under the wing of the Atomic Energy Commission.

The physicists are not unanimous in their reaction to these points, which cannot in any case be examined seriously from the point of view of France alone. The uncertainty hanging over the $300 \mathrm{GeV}$ of CERN, the ambiguous attitude of Germany which had envisaged a Franco-German $45 \mathrm{GeV}$ and which, tired of Paris beating about the bush, is now talking of building such an accelerator itself, has decidedly complicated the issue. However, whatever the position of the French particle physicists on the opportunity for building the $45 \mathrm{GeV}$ machine and on the choice of technical solutions, they would, at all events, like the government to make a quick and clear decision. They are also surprised, and apparently justifiably so, that the question of priority from which their subject has benefited is being called into question at this point, particularly so because the committee of wise men states that the effort has been a "paying one". A change in policy will surely compromise the results so far achieved-these have already for some time been a bit precarious because of the antiquated equipment -without necessarily making certain of marked progress in other fields of research. However, "a fine sprinkling of funds" has so often been a characteristic of French research and development programmes.

\section{Machine Minding}

Next month the British Computer Society will have to decide whether to go ahead with the plan to turn itself into a professional body. The plan, put forward in June 1967, proposes that the society should become the learned institution for computer scientists, establishing four grades of membership-student, associate, member and fellow. Ultimately, admission to the society will be controlled by examination, and the society aims to do for the computer scientists what the engineering institutions have done for the engineers.

Not all the present members of the society are enthusiastic about the plan. Some say that computer science is still too young and diffuse a discipline to be easily examinable, others that experience will always be worth much more than paper qualifications. Many of the existing members of the society are computer users rather than scientists, and one member of the society compared the present efforts with a hypothetical situation in which all those who used television sets had to become qualified as electronic engineers. For all this, the plan is almost certain to be approved at the extraordinary general mecting at the end of March.

The simple reason for this is the remarkable way in which the membership of the society has increased since the plan was announced. Although the reference books list the membership of the society as 3,000 , it has now reached a figure of $18,000,10,000$ of whom have joined since the new plans for the society became public knowledge. Although the secretary of the society, Mr J. G. Mackarness, sees this as evidence of general approval for the society's plans, others see it as a rush to get into the society before the examinations are established. Existing associate or ordinary members will be exempt from the examinations if they have more than seven years experience-if not, they will have to serve an apprenticeship as subscribing members until the seven years are up, when they will become members without cxamination. Existing student members will only have to take examinations if they are under twenty-one on May 1 this year.

In fact, the society had a problem in pitching the terms at exactly the right level. If all existing members had to take examinations - as properly they should if the society is to become as respectable as the engineering institutions-then new applicants would have been discouraged. The society admits that its reserves are "tiny", and hence needed to increase its subscription income substantially. This has been done most successfully, but possibly at the cost of losing credibility as a learned society. Moreover, subscription income will increase substantially again soon, for the rate for subscription is to double from $£ 5$ a year to $£ 10$ for members-a figure "very much in line with other professional bodies" according to $\mathrm{Mr}$ Mackarness, particularly as publications of the society are sent free to members. When the decision is taken at the end of March, only a fraction of the membership will be able to be present, but the rest-including those who have joined in the last year-will be able to vote by proxy.

\section{Too Many Institutions}

UNDETERRED by the refusal of the Institution of Heating and Ventilating Engineers to contemplate a merger with his institution, Mr H. G. Conway, president of the Institution of Mechanical Engineers, had another try on February 16 . He was invited to speak at the annual dinner of another engineering institution, the Institution of Plant Engineers, and made use of the occasion to offer the plant engineers a merger with his own institution. Mr Conway was anxious not to be cast in the role of an empire builder-"My own institution has no territorial ambitions or illusions of grandeur. We presidents come and go. . . . We speak of our profession as our conscience may dictate. Some of us feel that if a few of our institutions could get together we would have benefited the engineering profession as a whole".

The terms offered for the merger are generous, and very similar to those turned down by the Institution of Heating and Ventilating Engineers (see Nature, $21 \%, 498 ; 1968$ ). The plant engineers would form a divisional section with a good deal of autonomy. They could elect their own president and council, hold their own meetings and publish a journal. The alternatives, Mr Conway suggested, were either to apply for status as a chartered engineering bodywhich he thought unlikely to succeed, as there was a general view that the present proliferation of institutions is wrong-or become a technician body and aspire to chartered technician status.

The Institution of Plant Engineers is taking the offer quietly. It says only that it has "taken note" of Mr Conway's suggestion, which will be "carefully considered by the council of the institution", and a further statement will be made in due course. The 